\title{
DA MATERIALIDADE ÀS METÁFORAS BEM-SUCEDIDAS: REFLEXÓES SOBRE AS TRANSFORMAÇÓES MATERIAIS E REPRESENTATIVAS DO CORPO BIOLÓGICO ${ }^{1}$
}

\author{
Tatiana Gomes Rotondaro ${ }^{2}$
}

Resumo: A partir de uma análise sobre a utilização das biotecnologias médicas, este artigo pretende compreender como a disseminação de uma lógica e um discurso "informacional", na área de saúde, mascaram as intervençóes médicas efetuadas no corpo humano. Argumenta-se que frequentemente as práticas biotecnológicas são tratadas como meras relaçóes linguísticas, como se não fossem operaçóes de carne e sangue realizadas nos corpos. Para abordar a forma como essa lógica se processa, será feita, neste texto, uma breve discussão sobre como as disputas em torno do que são, e como operam os genes, acabam por reforçar um paradigma informacional, ainda que tal resoluçáo não seja amparada pelas evidências empíricas, mas em metáforas bem-sucedidas.

Palavras-chave: Filosofia da Biologia. Biotecnologias médicas. Genes. Corpo. Teoria Social.

\footnotetext{
${ }^{1}$ Parte dos argumentos desenvolvidos neste artigo foram apresentados, inicialmente, no XVII World Congress of Sociology, no Research Committee RC54 "The Body in the Social Sciences", sob o título: Bio-nano-info-technologies: ontological reflections on informational body", em julho de 2010.

Gostaria de agradecer aos colegas do Egenis, The Centre for the Study of Life Sciences, que me tornaram possível o conhecimento sobre esse debate, em especial, a John Dupré, que orientou meus estudos durante minha visita à Universidade de Exeter. Agradeço também aos comentários dos pareceristas anônimos, deixando claro que eventuais problemas que o artigo possa apresentar sấo de minha inteira responsabilidade.

${ }^{2}$ Professora de Sociologia da Universidade de São Paulo (USP), São Paulo, SP - Brasil. E-mail: tatiana. rotondaro@usp.br

Atua no Departamento de Economia (FEA) e no Programa de Pós-Graduação em Ciências Ambientais (PROCAM). Possui experiência em estudos na área de Teoria Social, Estudos em Ciência, Tecnologia e Sociedade e Sociologia Econômica e Ambiental. Atualmente, atua nos grupos de pesquisa "GovAmb - Laboratório de Governança Ambiental” e "Ética, tecnologia e economia digital”, desenvolvendo pesquisas sobre "Gestáo dos Comuns" e "Governança socioambiental em contexto de mudanças climáticas globais”.
}

http://dx.doi.org/10.1590/0101-3173.2018.v41n3.11.p213 


\section{APRESENTAÇÁO}

Este artigo tem como objetivo refletir sobre transformaçóes contemporâneas produzidas pelas ciências da vida acerca da percepção e da própria maneira de lidar com a materialidade da dimensão biológica dos seres humanos. A leitura aqui desenvolvida se desdobra a partir de uma análise sobre algumas implicaçóes que emergem sobretudo a partir do projeto de sequenciamento do genoma humano, bem como seu impacto sobre o desenvolvimento dos dispositivos médicos, principalmente da utilização de biotecnologias de aplicação médicas. Este texto se dedica a compreender como a disseminação uma determinada visão sobre os genes, assim como a transposição de uma lógica e um discurso que pretende sobrevalorizar os aspectos "informacional”, os quais estariam contidos nessa organela, penetram na área da saúde, mascarando intervençóes médicas efetuadas sobre corpos, que são muitas vezes apenas pensadas e tratadas em função da representação produzida através de exames clínicos. Argumento que frequentemente as práticas biotecnológicas são tratadas como meras relaçôes linguísticas, como se não fossem operaçóes de carne e sangue realizadas em corpos humanos. Para abordar a forma como essa lógica se processa, será feita, neste artigo, uma breve discussão sobre como as disputas em torno do que são, e como operam os genes, acabam por reforçar um paradigma informacional, embora tal resolução não seja amparada pelas evidências empíricas.

\section{GENE COMO LINGUAGEM E INFORMAÇÁO: FETICHISMO DO MAPA E A QUESTÁO DA METÁFORA}

Inspirada no fetichismo da mercadoria de Karl Marx, Donna Haraway (1997) analisa os efeitos causados pela disseminação do sequenciamento dos perfis genéticos como um tipo de "fetichismo do mapa". O fetichismo da mercadoria, conforme ensinado por Marx, é um tipo específico de reificação das interaçôes entre humanos, e destes com toda a sorte de "não-humanos" (que geralmente são chamados, na cultura ocidental, de "natureza"), os quais aparecem, durante a circulação de mercadorias, como "coisas". O fetichismo diz respeito a enganos, negaçóes, nos quais algum objeto substitui a ação de seres vivos (tanto humanos como naturais): coisas aparecem como geradoras de valor, ao passo que homens são tratados como meros apêndices de máquinas.

Segundo a análise de Donna Haraway, as biotecnologias certamente se encaixam nesse fetichismo da mercadoria clássico, endêmico às relaçóes capi- 
talistas de mercado. Nesse caso, genes substituem não apenas organismos, mas seres humanos e não-humanos de várias espécies, como geradores de valor. Entretanto, o caso das biotecnologias nos revela a existência de outros modos de reificação para além do fetichismo da mercadoria, o qual transmuta características materiais, contingentes, humanas ou não, em mapas da própria vida (lifeitself), e depois traz os mapas e suas entidades reificadas de volta ao mundo real, como geradoras de valor, conforme ocorre no mapeamento de genomas. A criação de mapas é necessária para "cercar" entidades e torná-las passíveis de exploração, de especificação, de venda, de uso etc. Ainda que possamos discutir essas práticas específicas, raramente discutimos os próprios mapas, pois estes nos são mostrados como fundaçóes confiáveis, livres de viés, garantidos pela pureza do número e da quantificação.

Do ponto de vista dos fetichistas, mapas - e objetos científicos em geral - são simples e puramente técnicos e representacionais, enraizados em processos de descoberta potencialmente livres de viés:

Mapas científicos não poderiam ser fetiches; fetiches são apenas para pervertidos e primitivos. Cientistas são comprometidos com a clareza; não são fetichistas atolados no erro. Meu mapa genético é uma representação não-trópica da realidade, ou seja, dos próprios genes. Esta é a estrutura da negação no fetichismo tecnocientífico. (HARAWAY, 1997, p. 137).

Entretanto, os mapas genéticos são fetiches, na medida em que são utilizados e interpretados como se fossem reais, literais, e não apenas processos que produzem uma representação dos corpos. Essa distorção, na prática científica e médica, acaba por transformar a produção do sequenciamento do mapa genético, ou seja, o produto dos processos técnicos em coisas mais reais e literais do que seus (corpos) representados, que pré-existem à prática e ao discurso.

Além desse tipo específico de fetichismo, não podemos descartar a ação eficiente que as metáforas têm apresentado na construção de uma concepção reificada da ação das biotecnologias. Em seu intuito de investigar a gênese histórica da metáfora genes-como-texto, Lenny Moss (2003) nos mostra que, correntemente, encontramos uma série de metáforas - tais como "mapa da vida", "chave da vida", "enciclopédia da vida" etc. - referindo-se às descobertas de sequenciamento genético. De certa forma, o diagnóstico de Moss sobre o papel das metáforas nas análises sobre o funcionamento dos genes parece coincidir com a já vista crítica social de Perry Anderson (1984) sobre a "exorbitação da 
linguagem” nas explicações pós-estruturalistas. Moss (2003) argumenta que, ao invés de as discussóes girarem em torno da realidade empírica alterada pelos genes, temos, contrariamente, o estabelecimento da metáfora como central para determinar o que é tido como realidade empírica:

$\mathrm{O}$ idioma da linguagem-do-gene torna-se escrito náo por aqueles cujas hipóteses foram bem-sucedidas, mas sim por aqueles cujas metáforas foram bem-sucedidas. As intuições dos críticos pós-modernos que vêem uma retórica descontrolada da vida que simplesmente constrói a si própria não podem ser responsavelmente ignoradas. (MOSS, 2003, p. xvii).

Richard Dawkins tem sido um dos maiores responsáveis, por meio de seus livros de divulgação científica, por disseminar essas metáforas. Segundo o autor, o DNA pode ser considerado como um conjunto de instruçóes (escrito no alfabeto $A, T, C$ e $G$ dos nucleotídeos) sobre como construir um corpo:

É como se em cada quarto de um imenso prédio existisse uma estante contendo os planos do arquiteto para todo o prédio. A "estante" em uma célula é chamada de núcleo. No homem, os planos do arquiteto montam 46 volumes - em outras espécies o número é diferente. Os volumes são chamados de cromossomos. [...] Farei uso da metáfora dos planos do arquiteto, misturando livremente a linguagem da metáfora com a linguagem da situação real. [...] A propósito, não há, é claro, nenhum "arquiteto". As instruçōes do DNA foram montadas pela seleçáo natural. (DAWKINS, 2001, p. 44-45).

Nessa metáfora, um gene é uma página de um determinado volume. Os 46 volumes (cromossomos) são, na verdade, 23 pares de volumes: cada par é composto por um volume da mãe e um do pai. Podemos chamar, então, os volumes de $1 \mathrm{a}, 1 \mathrm{~b}, 2 \mathrm{a}, 2 \mathrm{~b}$ etc. Um exemplo de como os genes dos pais interagem na formação do novo ser: "A página 6 do volume 13a e a página 6 do volume $13 \mathrm{~b}$, por exemplo, talvez 'refiram-se' ambas à cor dos olhos. Talvez uma queira dizer 'azul' e a outra 'castanho'.” (DAWKINS, 2001, p. 47).

\section{O SÉCUlo do GeNE}

Existem poucas dúvidas de que a ideia de "gene" se constituiu no tema central para a biologia do século XX (MOSS, 2003; KELLER, 2002), dentre outros. Por outro lado, a biologia, especialmente após o início de sua revolução molecular, durante as décadas de 40 e 50, tem progressivamente aumen- 
tado seu espectro de influência no âmbito acadêmico, incluindo filosofia, vida pública e política, medicina e ciências da saúde (MOSS, 2003; FOUCAULT, 1973). Mais recentemente, as promessas e prospectos da "nova biotecnologia" para curar doenças e oferecer novas opçóes reprodutivas e, correlativamente, para ganhar ou perder fortunas nas bolsas de valores, ambos ressaltados pela atenção da mídia que constantemente os associa ao Projeto Genoma Humano, têm dado à noção de gene uma maior proeminência pública.

A despeito da centralidade da categoria de gene, alguns filósofos e historiadores da biologia têm argumentado que nunca existiu de fato, em genética, uma definição de "gene" completamente aceita (FALK, 1986; KELLER, 2002; RHEINBERGER; MUELLER-WILLE, 2004). Além disso, especialmente depois da conclusão do Projeto Genoma Humano (HGP), quando se multiplicou o número de incertezas com relação às propriedades e às fundações dos genes, nós também passamos a testemunhar o surgimento de vozes questionando a validade de se falar sobre "gene" como algo tão bem determinado e determinável (MOSS, 2003; DUPRÉ, 2004).

Paradoxalmente, a própria noção de "gene" apresenta sinais de falência, num momento em que a moderna biologia molecular tem uma notoriedade pública sem precedentes. $\mathrm{O}$ debate público em torno das biotecnologias entrou em evidência em 1997, com o anúncio da clonagem da ovelha Dolly, atingindo seu ápice especialmente entre os anos de 2000 e 2003, quando tivemos desde notícias sobre a virtual finalização do sequenciamento do genoma humano ocupando as manchetes de todos os grandes jornais do mundo, até uma série de coberturas sobre a comemoração do cinquentenário da "descoberta" da dupla hélice do DNA, por James Watson e Francis Crick (LEITE, 2003). Além disso, uma série de debates e polêmicas em torno da utilizaçáo de OGMs - como por exemplo o processo iniciado no Brasil, em 1998, a respeito da regulamentação do plantio de soja transgênica -, de questôes éticas sobre a alteração genética de animais como os casos do oncomouse e da coelha Alba, dentre outros, alimentam o debate e as preocupaçóes em torno das biotecnologias.

Essa relação paradoxal entre hegemonia pública e "crise" científica da concepção de "gene" tem sido apontada como resultado da utilização política e retórica de um "determinismo genético" crescentemente irreconciliável com os resultados empíricos da pesquisa genômica atual. A complexidade verificada no genoma humano e em suas interaçóes com o meio desautoriza a manutenção de uma noçấo simples e unidirecional de causalidade, 
contrariamente ao pressuposto na ideia de gene como único portador de informaçâo, esteio da doutrina do determinismo genético (MOSS, 2003, p. iii; LEITE, 2003, 2005).

Conforme relata Leite (2003, p. 4, 2005),

o anúncio em fevereiro de 2001 dos trabalhos científicos com as sequências-rascunho do genoma humano, nas revistas Nature e Science, representou uma espécie de anticlímax. Tanto na imprensa especializada como na leiga, o tom de surpresa gravitou em torno do reduzido número total de "genes" (ou unidades transcricionais) identificados e estimados na análise das duas sequências do genoma humano, respectivamente 24.500 e 31.000 unidades transcricionais, no caso do Consórcio Internacional de Seqüenciamento do Genoma Humano, e 26.000 e 38.000, no caso da iniciativa liderada pela empresa Celera Genomics.

A quantidade média esperada de genes no ser humano girava em torno de 100.000, com estimativas entre 50.000 até mais de 140.000 (VENTER et al., 2001, p. 1305, 1346). Inicialmente, imaginava-se que, para cada proteína produzida por uma célula humana, deveria haver um "gene" correspondente. Essa "redução" do patrimônio genético humano força uma revisão da ideia de que haveria um gene para cada proteína, levando ao desenvolvimento da proteômica - análise da formação de proteínas no ambiente celular, tendo em vista as interaçôes do filamento formado pela "leitura" do DNA com os demais componentes do citoplasma.

Essas questôes têm estimulado o desenvolvimento da genômica, o qual se concentra em investigar até que ponto o genoma contém, ou é composto de alguma coisa que corresponde ao tradicional conceito de gene. Uma interpretação genômica avalia que traços característicos somente deveriam emergir de um certo tipo de configuração no genoma, e não de uma informação específica depositada em um único gene. A partir da perspectiva de Dupré (2004), talvez o desenvolvimento da genômica possa ser visto como um sucessor da genética tradicional.

Buscando uma forma de lidar com a polifonia das interpretaçóes sobre genes, Moss (2003) se engajou em seguir a reconstrução histórica e a análise conceitual do significado de "gene". De acordo com suas conclusões, é possível definir e distinguir dois tipos diferentes de genes. Cada um deles pode ser visto como consequência de uma de duas principais tendências históricas, para explicar a fonte da ordem biológica: pré-formacionismo e 
epigênese. $\mathrm{O}$ gene pré-formacionista (Gene-P) seria aquele que determinaria características fenotípicas, mas somente quando tomado a partir de uma perspectiva instrumental, que busca benefícios médicos e/ou econômicos imediatos. A metáfora frequentemente usada pelo autor para esse tipo de gene é o das "bonequinhas russas", onde, dentro de cada bonequinha, encontramos outra idêntica a ela. $\mathrm{O}$ gene da epigênese (Gene-D), ao contrário, é um recurso desenvolvimental que provê templates para o RNA e para a síntese de proteína, mas que não tem em si mesmo nenhuma relação com a determinação dos fenótipos dos organismos.

A ideia aparentemente prevalecente de que os genes constituem informação que determina características físicas (e de esboço para os organismos) está baseada, de acordo com essa perspectiva, em uma síntese não garantida desses dois tipos diferentes de genes que os está articulando, com efeito, através de um "grude retórico" (rhetorical glue) (MOSS, 2003, p. xiv).

\section{A GÊNESE do GENE COMO INFORMAÇÃo}

O "conhecimento" público sobre o que os genes podem fazer é frequentemente seguido por metáforas, tais como "deciframento, mapeamento e codificação", sugerindo um crescente controle da natureza e da vida, pela técnica, e um tipo de visão pré-formacionista sobre o desenvolvimento dos seres biológicos, em geral. Buscando fornecer uma explicação mais sociológica para esse fenômeno linguístico, dentro das ciências da vida, Leite (2005) argumenta que a incorporação dessas metáforas aconteceu em larga medida em função da adequação que elas apresentam para manter explicaçôes deterministas para o funcionamento da ciência e da tecnologia. Em suas análises dos artigos veiculados nos periódicos de alto impacto Nature e Science de fevereiro de 2001, Leite (2005) verificou que um complexo de metáforas informacionais e/ou linguísticas continua vivo nos textos publicados por biólogos moleculares na literatura científica.

Essa inadequação metafórica do gene como (sendo) o depositário de informação precisa a ser transmitida entre geraçôes tem sua origem no experimento mental feito por Erwin Schrödinger (1997 [1943]), em seu célebre livro O que é vida? (MOSS, 2003). Indagando sobre as características que uma molécula responsável pela hereditariedade supostamente deveria ter, o físico propôs uma analogia do gene com o desenvolvimento de um cristal aperiódico. Cabe lembrar que Schrödinger era um físico que havia apresentado 
grandes avanços no campo da química, com base na formulação do modelo molecular, o que talvez possa nos levar a especular se, em seu $O$ que é vida?, o autor não estava também buscando expandir sua esfera de influência para as ciências da vida.

Em função dessa analogia, os genes são concebidos e manipulados laboratorialmente como se fossem entidades bioquímicas. Entretanto, o conceito de gene, distintamente das outras entidades bioquímicas, não emergiu do logos da química. Diferentemente de proteínas, lipídios e carboidratos, os genes não nasceram de modo algum como entidades físicas, porém, como um tipo de representante (placeholder) em uma teoria biológica. Como a associação à etimologia da palavra genesis sugere, o gene indica aquele a partir do qual outras coisas surgem. Assim,

o conceito de gene começa não com a intenção de colocar um nome sobre algum pedaço de matéria, mas sim com a intençáo de se referir a alguma coisa desconhecida, seja lá o que essa alguma coisa possa vir a ser, que se acreditava ser responsável pela transmissão da forma biológica entre as geraçóes [...] o gene, para dizer o mínimo, é o membro mais peculiar de nossa atual miscelânea molecular. Atualmente, falamos de gene como uma sequência definida de ácidos nucléicos (DNA) com tanto suporte empírico quanto quando falamos de proteínas, lipídios, ou mesmo células e tecidos. (MOSS, 2003, p. 2).

Além disso, o conceito de gene é rotineiramente ampliado para outras entidades biomédicas. Por exemplo, certamente seríamos surpreendidos ao ouvir alguém atribuindo alguns aspectos de sua personalidade ao fato de seus pais terem oligossacarídeos para teimosia. Entretanto, oligossacarídeos, assim como genes, estão presentes em todas as células vivas. Será que faz algum sentido pensar que dois tipos de moléculas biologicamente onipresentes poderiam ser tão fundamentalmente diferentes, a ponto de fazer sentido falar de uma como um determinante da disposição de alguém para a teimosia, por exemplo? Como pode fazer algum sentido falar que uma espécie bioquímica é evidentemente inapropriada e que a outra é determinante de características humanas, para não mencionar a ideia de gene como uma espécie de "projeto" (blueprint) orientador para a construção de todo o organismo? (MOSS, 2003, p. 2).

Contudo, desde Watson e Crick (1953), o gene náo é mais um representante (placeholder) abstrato ou um lugar hipotético sobre uma estrutura citológica conhecida como cromossomo, mas ele tem sim sido 
compreendido como uma referência fisioquímica específica, isto é, como DNA. Assim, embora genes, como oligossacarídeos, sejam moléculas, eles (diferentemente de oligossacarídeos) também são concebidos como informação, blueprint, livros, receitas, programas, instruçôes e, mais, como agentes causais ativos, responsáveis por colocar a informação para usá-la como um programa que se autoexecuta.

De fato, a tarefa de explicar como uma simples matéria pode tornar-se organizada em um ser vivo tem sido uma das mais fundamentais e desafiadoras questôes de toda a tradição filosófico-científica ocidental, o que torna ainda mais curioso o fato de que cresce a percepção pública de que o gene poderia ser a resposta a essa questão. Pode o gene ser a resposta? Seria ele a ponte entre a simples matéria viva e a forma biótica organizada? (MOSS, 2003, p. 2-3). Existem aqueles que acreditam que sim. A existência do Projeto Genoma Humano (HGP) aponta para a seriedade dessa crença.

Para sustentar sua tese de que os modelos para explicar o funcionamento dos genes são disseminados por uma rhetorical glue equivocada, Moss utiliza a estratégia de reconstruir o caminho conceitual de nossa compreensão do gene como uma transformação altamente contingente daqueles conceitos de vida básicos que tiveram influência no século XIX. Porém, como argumenta o autor, contar essa história é complicado, devido à necessidade de desbancar dois mitos de grande penetração nas ciências da vida - nominalmente, que a biologia real somente começou com Darwin (1809-1882) e que a base conceitual da genética deve sua existência a alguma redescoberta incerta do trabalho de Mendel (1822-1884) (MOSS, 2003, p. xv).

Com relação às concepçóes de vida advindas do século XIX, Moss se apoia nas análises de Timothy Lenoir (1982), que atribui um papel distintivo à heurística teleológica neokantiana como guia para o tronco central da morfologia e fisiologia do início do século XIX. As iniciativas de Moss para avançar nessa ideia se referem à análise do caminho conceitual no qual a noção holística de Kant (1724-1804) e Blumenbach (1752-1840) é reformulada, sob a pressão para acomodar os processos darwinianos de variaçáo e seleção dentro de uma aglomeração de partes. É nessa transição e, em larga medida, como um tipo de efeito colateral conceitual, que o potencial holístico e, consequentemente, o organismo vivo, perdeu seu papel de protagonista no processo adaptativo (lamarckismo) para a máo invisível da seleção natural e, posteriormente, para o gene "egoísta". 
Argumento que não se pode simplesmente apreciar as mudanças e reviravoltas e as tensóes e bifurcaçóes do século $\mathrm{XX}$, sem reconhecer os marcos estabelecidos por essa transição. E me pauto pela perspectiva desenvolvida por Moss, ao sustentar: "Eu tenho me referido a esta transição como a 'virada filogenética' para marcar o movimento de abandono da ontogênese em direção à filogênese como o novo centro de gravidade para a explicação da forma biológica." (MOSS, 2003, p. xvi).

Usando os insights e reflexôes críticas de Wilhelm Johannsen (1857$1927)^{3}$ como ponto de partida, Moss introduziu uma distinção entre o Gene-P pré-formacionista e o Gene-D epigenético, como vimos anteriormente, e disso segue uma consideraçấo do que significaria para um gene satisfazer as condiçôes de ser quer um Gene-P, quer um Gene-D, simultaneamente.

Os frutos empíricos de várias décadas de pesquisa em biologia molecular, celular e desenvolvimental têm revelado que o que distingue uma forma biológica é raramente, se o é, a presença ou ausência de um certo modelo (template) genético, todavia, muito mais quando e onde os genes são expressos, como eles são modificados e, ainda, dentro de qual estrutura e dinâmica de relacionamento seus "produtos" estão inseridos. Esta é uma observação com grandes consequências mercadológicas, especialmente para o mercado virtual de patentes, uma vez que o que se patenteia é o gene isolado e não o que o gene faz dentro de contextos diferentes. Se genes existem para ser tanto moléculas com funçóes como modelos físicos para a síntese de outras moléculas $e$ determinantes de traços organísmicos e fenotípicos, então, de algum modo, genes teriam que, de fato, prover seus próprios instrumentos para uso. Eles teriam que ser hábeis para especificar onde e quando seus templates seriam colocados para uso, como tais produtos seriam modificados e alcançados, bem como em qual estrutura e dinâmica de relacionamento eles residiriam. Com efeito, é apenas nesse sentido que genes seriam capazes de ser aquilo que parece ser imputado a eles, ou seja: informação, programa, blueprint, enciclopédia da vida etc.

Localizando a fundação da metáfora do "gene como informação" na noção de Schrödinger de código da hereditariedade, Moss demonstra que o que se torna uma tradição retórica começa com um interesse empiricamente verificável, argumento que tem sido esquecido ou ignorado:

\footnotetext{
${ }^{3}$ Foi Wilhelm Johannsen quem introduziu os termos "gene", "genótipo" e "fenótipo", e o fez precisamente como uma crítica às falácias pré-formacionistas e em nome de um retorno a um holismo, definido em termos de toda a extensão dos potenciais desenvolvimentais fenotípicos associados com qualquer genótipo.
} 
Schrödinger não tinha como observar a dinâmica neguentrópica dos processos moleculares intracelulares. Sua visão de código de hereditariedade [hereditarycode-script] é tal que isola a fonte de resistência à entropia dentro do núcleo, na verdade tal isolamento continua a ser implicado pela tradição retórica que distingue o genoma como fonte de informação biológica. Empiricamente, sugiro, simplesmente não há tal partição nem qualquer fluxo assimétrico de "ordem". A descrição de Schrödinger de ordem-a-partir-da-ordem caracteriza bem a célula como um todo - mas apenas como um todo. (MOSS, 2003, p. 91, grifo nosso).

De certa forma, a própria consolidação de um paradigma linguístico, no pós-Segunda Guerra - como consequência não intencional e, num certo sentido, invertida -, ajudou a difundir e legitimar uma determinada compreensão sobre o funcionamento dos genes que não se sustenta empiricamente, uma vez que, como nos lembra Leite (2005), este expressaria a marca de uma compreensão de mundo determinista para o trato das questóes tecnológicas em geral. De certo modo, ainda que parte do projeto pós-estruturalista tivesse como objetivo fazer uma crítica radical da razão, através de uma radical relativização da "verdade", produzida também pela realidade empírica, a minimização conflitual de visôes de mundo distintas acabou abrindo espaço para que uma retórica comprometida com um projeto tecnológico e científico determinista penetrasse em camadas mais profundas da vida social, por meio da disseminação de um discurso elaborado através de uma "textualidade metafórica” conveniente (ROTONDARO, 2008).

\section{Corpo InFormacional}

$\mathrm{Na}$ contramáo de ideias que supervalorizam o aspecto informacional da genética, trago para o debate as contribuiçóes de Catherine Waldby (1997), que argumenta que a informatização da medicina também envolve uma reorganizaçáo material de (pelo menos alguns) corpos, uma vez que os nossos corpos são o material sobre o qual as tecnologias médicas operam. Tais tecnologias médicas são, de certa maneira, ambíguas quando localizadas dentro da história da tecnologia, no sentido de que, por um lado, elas são não apenas assimiladas pelas narrativas de progresso da civilização ocidental, mas algumas vezes são apresentadas como paradigmas desse progresso; por outro lado, como nossos corpos são o objeto material dessa tecnologia, torna-se difícil sustentar um senso de que "nós" temos o domínio sobre tais técnicas e, consequentemente, sobre o progresso das culturas ocidentais. 
Mais do que simples ferramentas, as tecnologias médicas podem ser mais bem abordadas pelo termo cunhado por Foucault (1979), "tecnologias de poder", formas de práticas racionais e materiais que são indissociáveis do exercício do poder sobre os sujeitos corporificados. O propósito das tecnologias de poder é organizar e explorar a materialidade do corpo, quer nos interesses da ordem social, quer na geração de certo tipo de conhecimento obtido com a observação dos corpos no espaço social, seus comportamentos e capacidades. Nesse sentido, o conhecimento médico é gerado através de técnicas de poder e confere corpos disponíveis para o uso social.

Para Waldby (1997), vivemos um momento particular na história das tecnologias médicas, com o crescente emprego de computadores na visualização dos corpos, em cirurgias, pesquisas e armazenagem de dados. Cada vez mais a tela de computador provê a estrutura através da qual os corpos são vistos e compreendidos dentro da prática médica. Pela análise do visible human project, a autora demonstra como a tecnologia do computador está trabalhando sobre os corpos e sua própria imagem. De fato, a convergência conceitual entre corpos concebidos medicamente e computadores é amplamente reconhecida nos cultural studies e na sociologia da medicina e saúde (HARAWAY, 1991; FOX-KELLER, 1995), porém, o ponto enfatizado por Waldby é que "esta convergência não é só conceitual, mas também material, envolvendo a literal reorganização da carne.” (WALDBY, 1997, p. 2).

O computador, não entendido como ferramenta, mas como filosofia e práxis cibernética, não é o melhor espelho para um corpo natural, pré-existente, mas sim participa em uma transformaçáo histórica dos corpos, que está tomando espaço através de discursos médicos e outros âmbitos sociais. (WALDBY, 1997, p. 3).

Segundo o argumento de Waldby, mais do que prover um espelho para o corpo, os computadores têm-se tornado, principalmente nos últimos 40 anos, a tecnologia que enclausura (enframe) o corpo em uma visáo médica, o meio através do qual ele é representado e reordenado dentro dos termos do discurso biomédico. Por meio do recurso de situar o objeto em um campo de visão particular, no caso, a tela do computador, temos a ocorrência de um processo de representação que não é neutro, porém, que carrega um significado particular e consequências para dentro dele mesmo, ao apresentar o mundo para o observador de uma maneira particular: 
Heidegger entende que o enframing tecnológico envolve a representação do mundo como essencialmente matemático, uma entidade ordenada que está disponível para intervenção e apropriação tecnológica. Sendo uma tecnologia de enframing, o computador organiza os termos nos quais o corpo é entendido, mais do que refleti-lo transparentemente em sua organicidade apriorística. (WALDBY, 1997, p. 3).

Isso é evidente no modo como o computador tem-se tornado a "tecnologia definidora" para o modelo médico do corpo, provendo a metáfora primária através da qual o corpo é concebido, assim como o instrumento por meio do qual o corpo é contemplado. Em formas computadorizadas, o corpo é pintado como um dado digital, similar a uma imagem produzida por intermédio de uma estrutura de dados matemáticos. Esse modo de ver opera recursivamente, ao escorar uma crescente tendência médica de entender a composição do corpo como um arquivo de "dados" de DNA, o qual pode ser arquivado, recuperado e reescrito, ou como um sistema de comunicação onde organismos coerentes são mantidos por meio da troca de informaçáo (HARAWAY, 1991). O próprio processo da vida é entendido como um dado. A morte é, correlativamente, uma falha de informação, e doenças como a AIDS procedem por uma "reprogramação" viral do sistema imune do corpo:

O computador é entấo uma tecnologia definidora para a medicina náo por causa da proliferaçáo de seus instrumentos, mas por causa da ideia do computador, de um ativo e interativo sistema complexo de processamento e troca de informação, que tem reconfigurado a ideia de corpo. (WALDBY, 1997, p. 4).

Tal reconfiguração do corpo, (re-)construindo-o cada vez mais como "corpo informacional", não diz respeito a construçôes puramente metafóricas ou conceituais, mas, ao contrário, atinge o núcleo do corpo, por meio de práticas de inscrição e reordenação material, um novo modo de transgressão material implícito na ideia de enframing, uma vez que corpos e partes do corpo são ajustados aos interesses da máquina.

\section{ReFLEXÓEs FinAIS}

Na primeira parte do texto, embora de maneira sucinta, procurei apresentar e sistematizar alguns processos sociais relativos ao próprio desenvolvimento da lógica de construção dos fatos científicos e dispositivos tecnológi- 
cos, que levaram à difusão da compreensão dos genes construída a partir de metáforas bem-sucedidas e convenientes sobre o que seriam essas entidades biológicas e qual a sua função. Com a narrativa apresentada para descrever essa história, busquei trazer elementos que nos permitissem ter alguma dimensão sobre a importância e o alcance que a virada linguística teve, em todas as áreas da vida social, na medida em que representou uma mudança coletiva dos próprios processos discursivos e cognitivos que compartilhamos e reproduzimos socialmente. Nesse sentido, argumento que a proliferaçáo e a legitimidade construídas em torno de uma visão progressivamente distanciada dos aspectos materiais dos genes - inicialmente no âmbito científico, mas que logo se dissemina socialmente e politicamente - se colocaram de forma paradigmática para transformar a compreensão social não apenas dos genes, mas das próprias (bio) tecnologias e práticas médicas que se aperfeiçoaram a partir dessa "descoberta".

Por fim, ao trazer os argumentos de Waldby para o debate, procurei ilustrar como a difusão de uma lógica de pensamento sobre os "genes como informação" (ou seja, como depositário de uma informação determinística acerca do desenvolvimento do organismo), ainda que sustentada sobre "metáforas bem-sucedidas”, tem contribuído para o remodelamento da própria visão contemporânea sobre os corpos, os quais progressivamente são percebidos e reduzidos à sua concepção somática e informacional, onde qualquer doença (ou desajuste) passa a ser interpretado como um desequilíbrio físico-químico, tornando a dimensão sobre a subjetividade humana um objeto inconveniente, que se mantenha no vocabulário de forma residual - em que pese aos significativos movimentos de resistência a disseminação desse projeto civilizacional.

ROTONDARO, T. G. From materiality to successful metaphors: reflections on material and representative transformations of the biological body. Trans/formlação, Marília, v. 41, n. 3, p. 213-228, Jul./Set., 2018.

\footnotetext{
Abstract: Starting with an analysis of the use of medical biotechnology, this article aims to understand how medical interventions in the human body are masked by a certain logic and by an "informational" discourse on health care. We argue that biotechnological practices are often treated as linguistic relations, as if they were not flesh and blood operations on bodies. To address how this logic is processed, we discuss how disputes over the nature and functioning of genes end up strengthening an informational paradigm that is not based on empirical evidence, but rather on successful metaphors.
}

Keywords: Philosophy of biology. Medical biotechnology. Genes. Body. Social theory. 


\section{REFERÊNCIAS}

ANDERSON, P. A crise da crise do marxismo. São Paulo: Brasiliense, 1984.

DAWKINS, R. O gene egoísta. Belo Horizonte: Itatiaia, 2001.

DEBRUN, M. A dinâmica da auto-organização primária. In: Auto-organização: estudos interdisciplinares em filosofia, ciências naturais e humanas e artes. Campinas: UNICAMP, CLE, 1996. p. 25-59.

DUPRÉ, J. Understanding contemporary genomics. Perspectives on Science, v. 12, n. 3, p. 320-338, 2004.

FALK, R. What is a gene? Studies in the History and Philosophy of Science, v. 17, n. 2, p. 133-173, 1986.

FOUCAULT, M. The birth of clinic: an archeology of medical perception. London: Tavistoc, 1973. . Microfisica do poder. Rio de Janeiro: Graal, 1979.

HARAWAY, D. Simians, cyborgs and women: the reinvention of nature. London: Free Association Books, 1991.

.Modest_witness@second_millennium. Femaleman_meets_oncomouse: feminism and technoscience. New York, London: Routledge, 1997.

KELLER, E. F. Refiguring life: metaphors of twentieth-century biology. New York: Columbia University Press, 1995.

. O século do gene. Belo Horizonte: Crisálida, 2002.

LEITE, M. Hegemonia e crise na noção de "gene" nos 50 anos do DNA. In: CONGRESSO NACIONAL DE GENÉTICA, 49. Águas de Lindóia, SP. Anais... Águas de Lindóia, SP: Sociedade Brasileira de Genética, 2003.

. Biologia total: hegemonia e informação no genoma humano. 2005. 225f. Tese (Doutorado em Sociologia) - Instituto de Filosofia e Ciência Humanas, Universidade Estadual de Campinas (UNICAMP), Campinas, 2005.

LENOIR, T. The strategy of life: teleology and mechanics in nineteenth century german biology. Dordrecht and Boston: D. Reidel, 1982.

MOSS, L. What genes can't do? Cambridge, Mass.: MIT Press, 2003.

RHEINBERGER, H-J.; MÜLLER-WILLE, S. Gene. In: The Stanford Encyclopedia of Philosophy, 2004. Disponível em: <http://www.seop.leeds.ac.uk/entries/gene/>. Acesso em: 20 abr. 2008.

ROTONDARO, T. Neomaterialismo genômico: as novas biotecnologias e os desafios contemporâneos da teoria crítica. 2008. Tese (Doutorado em Sociologia) - Instituto Universitário de Pesquisas do Rio de Janeiro (IUPERJ), Rio de Janeiro, 2008. 
ROTONDARO, T. G.

SCHRÖDINGER, E. O que é vida? São Paulo: Editora da UNESP, 1997 [1943].

VENTER, J. C. et al. The sequence of the human genome. Science, v. 291, n. 5507, p. 1304-1351, fev. 2001.

WALDBY, C. The body and the digital archive: the visible human project and the computerisation of medicine. Health: An Interdisciplinary Journal for the Social Study of Health, Illness and Medicine, v. 1, n 2, p. 227-243, 1997.

Recebido: 2015-06-11

Aceito: 2016-04-01 